\title{
UPAYA PANTI ASUHAN PUTRI AISYIYAH BABAT LAMONGAN SEBAGAI STRATEGI MENCAPAI KEMANDIRIAN FINANSIAL1
}

\author{
Rembrant Shella Gustami \\ Departemen Ekonomi Syariah-Fakultas Ekonomi dan Bisnis-Universitas Airlangga \\ Email: rembrant.ella.gustami-2015@feb.unair.ac.id
}

\section{Muhammad Nafik H.R}

Departemen Ekonomi Syariah-Fakultas Ekonomi dan Bisnis-Universitas Airlangga Email: muhammadnafik@feb.unair.ac.id

\begin{abstract}
:
The background of this study is a financial surplus situation at the Aisyiyah Female Orphanage Babat in the last 4 years. This phenomenon encourages researchers to raise research that discusses the financial independence strategy that is implemented until the manager can fund the needs of the orphanage without prioritizing donation funds. This study uses a qualitative approach with a case study strategy. Data collection is done through interview techniques with relevant parties and related documents. The data analysis technique used is making explanations. The results of this study indicate that Aisyiyah Female Orphanage can be said to be financially independent. Independence is achieved by implementing a number of strategies including conducting several business ventures, implementing an independent financial management system, fostering entrepreneurial spirit of foster children, determining the priority of sources of income and fostering a spirit of sharing with others in foster children. Keywords: financial, strategy, financial independence, Aisyiyah Female Orphanage, Babat
\end{abstract}

\section{PENDAHULUAN}

Islam mengajarkan bahwa anak merupakan amanah sekaligus karunia yang diberikan Allah SWT kepada manusia, sehingga Islam memberikan perhatian yang tinggi kepada anakanak. Amanah tersebut harus kita jaga dengan baik karena anak juga sebagai generasi penerus bangsa, agama, dan keluarga. Oleh sebab itu, segala kebutuhan anak baik secara fisik, sosial, maupun mental harus terpenuhi dengan baik demi terbentuknya generasi yang berkualitas. Hal tersebut tertulis dalam QS. An-Nisa ayat 9 yang berbunyi :

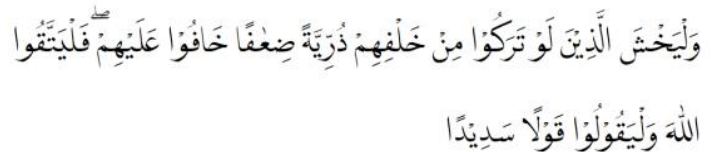

walyakhsyallażina lau taraku min khalfihim żurriyyatan di'āfan khāfụ 'alaihim falyattaqullāha walyaqụlụ qaulan sadīdā

Artinya: "Dan hendaklah takut kepada Allah orang-orang yang seandainya meninggalkan dibelakang mereka anak-anak yang lemah, yang mereka khawatir terhadap (kesejahteraan) mereka. Oleh sebab itu hendaklah mereka bertakwa kepada Allah dan hendaklah mereka mengucapkan perkataan yang benar." (QS. An-Nisa: 9)

\footnotetext{
${ }^{1}$ Jurnal ini merupakan bagian dari skripsi Rembrant Shella Gustami, NIM: 041511433082, yang diuji pada tanggal 25 Juni 2019.
} 
Gustami, et al/Jurnal Ekonomi Syariah Teori dan Terapan Vol. 6 No. 7 Juli 2019: 1509-1520; UPAYA PANTI ASUHAN PUTRI AISYIYAH BABAT LAMONGAN SEBAGAI STRATEGI MENCAPAI KEMANDIRIAN FINANSIAL

Setiap anak berhak mendapatkan hak dan kewajiban yang setara satu sama lain dalam hal pendidikan yang layak. Kelvarga yang tidak mampu memenuhi hak ekonomi anak tersebut sangat mengharapkan uluran tangan dari pihak lain yang memiliki kepedulian akan pendidikan.

Hak tersebut layak didapat baik melalui pemerintah maupun lembaga soial lain yang juga memiliki kepedulian. Untuk mendapatkan hak-haknya, anak memerlukan perlindungan, khususnya perlindungan hukum. Dasar hukum perlindungan anak di Indonesia tercantum dalam Undang-undang No.23 Tahun 2002 tentang Perlindungan Anak Pasal 20, yang mencantumkan bahwa "Negara, pemerintah, masyarakat, keluarga dan orang tua berkewajiban dan bertanggung jawab terhadap penyelenggaraan perlindungan anak."

Permasalahan yang terjadi adalah masih banyak anak Indonesia yang tidak mendapat jaminan pendidikan dan kesejahteraan hidup. Keadaan ini disebabkan salah-satunya oleh faktor kemiskinan. Walaupun pemerintah pusat dan beberapa pemerintah daerah telah mengurangi beban biaya pendidikan bagi siswa kurang mampu, tidak sedikit anak-anak kurang mampu yang belum terjangkau oleh kebijakan tersebut. Dampak yang terjadi adalah anak-anak telantar dan putus sekolah bahkan menjadi anak jalanan, terlebih jika mereka adalah anak yatim-piatu. Hal ini tentunya menimbulkan efek negatif bagi anak tersebut dan bagi masyarakat. Menurut data Badan Pusat Statistik, pada tahun 2006 jumlah anak telantar yang berusia 6- 18 tahun mencapai 2.815 .393 anak, balita telantar mencapai 518.296, anak perlakuan salah 182.408, anak jalanan 232.894 dan anak nakal sebanyak 295.763, dengan rincian yang tinggal di perkotaan sebanyak 492.281 jiwa dan di pedesaan mencapai 2.275.348. Adapun yang tergolong rawan ketelantaran diperkirakan mencapai 10.322.764 orang.

Pendirian lembaga sosial atau yayasan merupakan salah satu cara untuk mengatasi masalah tersebut, khususnya lembaga sosial dalam bidang pengasuhan anak, yakni yayasan panti asuhan.

Yayasan Panti Asuhan Putri Aisyiyah Babat pada awalnya memiliki dana yang masih sedikit dan masih mengharap bantuan dari donatur serta pemerintah, namun ternyata bantuan dari pemerintah bersifat tidak tetap, sedangkan kebutuhan terus meningkat.

Kebutuhan operasional panti asuhan, seperti kebutuhan makanan, pakaian, listrik dan lain-lain kemudian dipenuhi dengan menggunakan dana dari bantuan donatur sosial seperti sumbangan masyarakat yang tidak mengikat, dana zakat, infak dan sedekah (ZIS) kaum muslimin. Donasi 
tersebut juga bersifat tidak tetap, sehingga Panti Asuhan Putri Aisyiyah Babat akan sangat rawan menghadapi kesulitan keuangan apabila pengeluaran operasional lebih besar daripada dana bantuan yang diperoleh. Dengan keadaan tersebut pengurus panti harus dapat mengatur keuangan panti dengan baik serta mencari strategi agar kekurangan dana dapat diminimumkan serta mencapai kemandirian finansial.

Mandiri secara finansial berarti sebuah lembaga tidak lagi bergantung pada dana dari pihak lain untuk memenuhi kebutuhannya. Panti Asuhan Putri Aisyiyah Babat ini merupakan salah satu panti yang telah mencoba berbagai jenis usaha bisnis untuk memenuhi kebutuhannya dan sebagai upaya mencapai kemandirian. Hal ini terlihat pada arus kas panti selama 4 tahun terakhir yang tidak pernah mengalami defisit. Sebagaimana yang terlihat dalam tabel 1. berikut ini.

Tabel 1.

Arus Kas Panti Asuhan Putri Aisyiyah Babat (2015-2018)

\begin{tabular}{|c|c|c|c|}
\hline $\begin{array}{c}\text { Tah } \\
\text { un }\end{array}$ & $\begin{array}{c}\text { Penerim } \\
\text { aan }\end{array}$ & $\begin{array}{c}\text { Pengelua } \\
\text { ran }\end{array}$ & $\begin{array}{c}\text { Surplus/D } \\
\text { efisit }\end{array}$ \\
\hline $\begin{array}{c}\mathbf{2 0 1} \\
\mathbf{5}\end{array}$ & $\begin{array}{c}504.756 .0 \\
00\end{array}$ & $\begin{array}{c}\text { Rp. } \\
490.649 .0 \\
00\end{array}$ & Surplus \\
\hline $\mathbf{2 0 1}$ & Rp. & Rp. & \\
$\mathbf{6}$ & $\begin{array}{c}440.133 .0 \\
00\end{array}$ & $\begin{array}{c}343.064 .0 \\
00\end{array}$ & Surplus \\
\hline $\mathbf{2 0 1}$ & Rp. & Rp. & Surplus \\
$\mathbf{7}$ & 530.496 .0 & 480.855 .0 & \\
\hline
\end{tabular}

\begin{tabular}{|c|c|c|l|}
\hline & 00 & 00 & \\
\hline $\mathbf{2 0 1}$ & Rp. & Rp. & \\
$\mathbf{8}$ & 753.858 .0 & 598.310 .0 & Surplus \\
& 00 & 00 & \\
\hline
\end{tabular}

Sumber: Laporan Keuangan Panti Asuhan Putri Aisyiyah Babat diolah kembali

Dari tabel di atas, terlihat bahwa Panti Asuhan Putri Aisyiyah Babat tidak pernah mengalami defisit. Sisi penerimaan mengalami naik turun namun memiliki trend yang positif naik.

\section{LANDASAN TEORI}

Panti Asuhan atau Panti Sosial Asuhan Anak demikian juga Lembaga Kesejahteraan Sosial Anak (LKSA) adalah lembaga sosial nirlaba yang menampung, mendidik dan memelihara anak-anak yatim, yatim piatu dan anak telantar. Menurut Nabor dalam Bardawi Barzan (1999: 5) : "Panti asuhan adalah suatu lembaga pelayanan sosial yang didirikan oleh pemerintah maupun masyarakat, yang bertujuan untuk membantu atau memberikan bantuan terhadap individu, kelompok masyarakat dalam upaya memenuhi kebutuhan hidup".

Panti asuhan merupakan lembaga pelayanan sosial yang memberi perlindungan anak yatim, yatim piatu, dan anak telantar. Lembaga tersebut berfungsi memberi perlindungan kepada hak anak-anak sebagai pengganti orang tua dalam memenuhi kebutuhan mental dan sosial pada anak-asuh. Perlindungan tersebut 
Gustami, et al/Jurnal Ekonomi Syariah Teori dan Terapan Vol. 6 No. 7 Juli 2019: 1509-1520; UPAYA PANTI ASUHAN PUTRI AISYIYAH BABAT LAMONGAN SEBAGAI STRATEGI MENCAPAI KEMANDIRIAN FINANSIAL

dimaksudkan agar mereka memiliki kesempatan untuk mengembangkan diri serta mampu melaksanakan peran mereka sebagai individu dan warga negara didalam kehidupan bermasyarakat.

Kemandirian keuangan daerah menurut Halim (2007) yaitu menunjukkan kemampuan pemerintah daerah dalam membiayai sendiri kegiatan pemerintahan, pembangunan dan pelayanan kepada masyarakat yang telah membayar pajak dan retribusi sebagai sumber pendapatan yang diperlukan daerah. Kemandirian kevangan daerah ditujukan oleh seberapa besar kecilnya pendapatan asli daerah (PAD) dibandingkan dengan pendapatan daerah yang berasal dari sumber lain, misalnya bantuan pemerintah pusat ataupun dari pinjaman.

Strategi kemandirian finansial panti asuhan merupakan sebuah alat atau perencanaan untuk mencapai suatu tujuan yang telah ditetapkan panti yang dalam hal ini adalah mandiri secara finansial.

\section{METODE PENELITIAN}

\section{Pendekatan Penelitian}

Penelitian ini menggunakan pendekatan kualitatif. Strategi yang digunakan dalam penelitian ini adalah studi kasus. Menurut Yin (2013:1), Studi kasus merupakan strategi yang paling cocok bila pertanyaan suatu penilitian berkenan dengan how atau why, bila peneliti hanya memiliki sedikit peluang untuk mengontrol peristiwa peristiwa yang akan di selidiki dan bilamana fokus penelitian terletak pada fenomena masa kini di dalam konteks kehidupan nyata.

\section{Ruang Lingkup Penelitian}

Batasan atau ruang lingkup penelitian ini difokuskan pada strategi yang dilakukan Panti Asuhan Putri Aisyiyah Babat dalam mencapai kemandirian finansial khususnya pada strategi pengumpulan dana dan pengalokasian dana.

\section{Jenis dan Sumber Data}

Sumber data yang digunakan dalam penelitian ini adalah data primer dan data sekunder. Data primer adalah yang diperoleh langsung dari sumbernya melalui wawancara dengan pihak Panti Asuhan Putri Aisyiyah Babat. Data sekunder penelitian ini diperoleh dari studi kepustakaan terkait panti asuhan dan kemandirian finansial lembaga.

\section{Unit Analisis}

Unit analisis dalam penelitian ini adalah Yayasan Panti Asuhan Putri Aisyiyah Babat, Pengurus Panti Asuhan Putri Aisyiyah Babat, dan strategi kemandirian finansial yang dilakukan Yayasan Panti Asuhan Putri Aisyiyah Babat yang termasuk didalamnya segala aktivitas pendanaan yang dilakukan Panti Asuhan dalam rangka memenuhi kebutuhan pengeluaran.

\section{Teknik Pengumpulan Data}


Gustami, et al/Jurnal Ekonomi Syariah Teori dan Terapan Vol. 6 No. 7 Juli 2019: 1509-1520; UPAYA PANTI ASUHAN PUTRI AISYIYAH BABAT LAMONGAN SEBAGAI STRATEGI MENCAPAI KEMANDIRIAN FINANSIAL

$\begin{array}{ccccc}\text { Langkah-langkah } & \text { yang } & \text { pembuatan } & \text { eksplanasi } & \text { untuk } \\ \text { dilakukan dalam } & \text { prosedur } & \text { menjelaskan } & \text { fenomena } & \text { atau }\end{array}$
pengumpulan data adalah:

1. Peneliti melakukan persiapan awal dengan menyiapkan surat dari Fakultas Ekonomi dan Bisnis Universitas Airlangga untuk izin mewawancarai.

2. Peneliti melakukan wawancara kepada pihak Panti Asuhan Putri Aisyiyah Babat terkait dengan kemandirian finansial dan strategistrategi yang dilakukan untuk mencapai hal tersebut. Setelah melakukan wawancara, peneliti meminta data keuangan kepada panti.

\section{Teknik Keabsahan Data}

Penelitian ini menggunakan
teknik triangulasi untuk menguji
keabsahan data. Teknik triangulasi
adalah teknik pemeriksaan yang
memanfaatkan sesuatu yang lain.
Terdapat tiga teknik triangulasi yaitu
triangulasi sumber, triangulasi teknik dan
triangulasi waktu. Triangulasi yang
digunakan dalam penelitian ini adalah
triangulasi sumber yaitu dengan
membandingkan keselarasan hasil
wawancara antara pihak yang terkait
yaitu ketua, bendahara, dan ketua
pengelolaan usaha Panti Asuhan Putri
Aisyiyah Babat.

\section{Teknik Analisis Data}

Dalam penelitian ini, peneliti menggunakan teknik pembuatan eksplanasi. Menurut Yin (2013) menetapkan serangkaian timbal balik mengenai fenomena tersebut. Dari proses analisis ini semua data yang diperoleh akan diolah kembali, dihubungkan, dan dibandingkan sehingga dapat diketahui masingmasing terkait strategi yang diterapkan Panti Asuhan Putri Aisyiyah Babat untuk mencapai kemandirian finansial.

\section{HASIL DAN PEMBAHASAN}

Panti Asuhan Putri Aisyiyah Babat mengelompokkan jenis kemandirian menjadi 3 antara lain:

1. Kemandirian belajar

Kemandirian belajar ini sangat diperlukan agar seseorang khususnya dalam hal ini siswa dapat memiliki pencapaian prestasi belajar yang optimal. Kemandirian untuk belajar tidak dengan mudah dimiliki oleh anak asuh, hal tersebut karena latar belakang anak berbeda-beda.

2. Kemandirian organisasi dan sosialisasi

Kemandirian organisasi dan sosialisasi pada anak asuh adalah kondisi ketika anak asuh dapat berinteraksi dengan baik di lingkungan sekitar.

3. Kemandirian Finansial

Kemandirian finansial adalah kondisi ketika seseorang mampu membiayai kebutuhan hidupnya tanpa bergantung kepada orang lain. Mandiri secara finansial berarti 
Gustami, et al/Jurnal Ekonomi Syariah Teori dan Terapan Vol. 6 No. 7 Juli 2019: 1509-1520; UPAYA

PANTI ASUHAN PUTRI AISYIYAH BABAT LAMONGAN SEBAGAI STRATEGI MENCAPAI KEMANDIRIAN

FINANSIAL

seseorang bertanggung jawab atas pemenuhan kebutuhannya sendiri.

Kemandirian finansial

merupakan hal yang penting dalam kehidupan seseorang maupun lembaga. Kemandirian finansial merupakan kemampuan seseorang dalam menghadapi kehidupannya tanpa bergantung kepada orang lain terutama dalam hal finansial. Manusia mandiri adalah ia yang mampu bertanggung jawab, mengatasi masalah, dan mengambil keputusan dengan mengandalkan dirinya sendiri.

Islam menganjurkan pemeluknya untuk bekerja dan berusaha mencari rezeki. Bekerja adalah fitrah sekaligus merupakan salah satu identitas manusia, sehingga bekerja yang didasarkan pada prinsipprinsip iman tauhid, tetapi sekaligus meningkatkan martabatnya sebagai hamba Allah SWT yang mengelola seluruh alam.

Ketua Panti Asuhan Putri Aisyiyah Babat mengatakan bahwa sebuah panti asuhan memang baik untuk mandiri secara finansial. Dengan begitu ia mampu menghidupi dirinya sendiri, tidak bergantung pada bantuan orang lain. Akan tetapi, panti asuhan merupakan lembaga sosial yang pada akhirnya tidak akan lepas dari bantuan. Panti asuhan tetap akan menerima ketika ada bantuan yang datang. Lepas dari hal tersebut, panti asuhan harus tetap mempersiapkan diri jika suatu hari tidak ada bantuan yang masuk. Seperti yang dilakukan Panti Asuhan Putri Aisyiyah Babat dalam berupaya menyusun Rencana Anggaran Panti untuk mempersiapkan sumber penerimaan dan pengeluaran panti.

Sumber penerimaan bagi Panti Asuhan Putri Aisyiyah Babat yaitu berasal dari donatur dan hasil pengelolaan usaha bisnis.

Komponen sumber modal panti adalah 30\%-40\% berasal dari donatur dan sisanya $60 \%-70 \%$ berasal dari hasil usaha bisnis panti. Saat ini panti tidak mengutamakan dana dari donatur sebagai penerimaan utama dalam manajemen keuangannya, kebutuhan operasional panti asuhan dan kebutuhan sehari-hari anak asuh diutamakan berasal dari penerimaan hasil laba usaha.

Prosentase sumber dana dari hasil usaha dan donasi adalah $75 \%$ : 25\%. Prosentase ini sedikit berbeda dengan pendapat ibu Riyantun yang hanya menyampaikan skala $60 \%-70 \%$ saja. Namun hasil tersebut menunjukkan bahwa Panti Asuhan Putri Aisyiyah Babat sudah dapat dikatakan mandiri secara finansial meskipun belum 100\%, karena kemandirian keuangan terjadi ketika sebuah organisasi memiliki dana hasil usaha sendiri yang lebih besar daripada dana yang diperoleh dari eksternal. (Halim, 2015) 
Panti Asuhan Putri Aisyiyah mampu untuk lebih mandiri dalam memenuhi kebutuhannya, namun dibutuhkan usaha yang lebih besar agar hasil yang didapat juga besar. Angka $75 \%$ sudah dicapai untuk menjadi mandiri, dibutuhkan $25 \%$ agar Panti Asuhan Putri Aisyiyah Babat dapat memenuhi segala kebutuhannya dari hasil pengelolaan usaha.

Strategi menuju kemandirian secara finansial yang menjadi fokus penelitian ini. Untuk mencapai hal tersebut, Panti Asuhan Putri Aisyiyah Babat saat ini telah mengupayakan berbagai kegiatan untuk mencapai kemandirian finansial, beberapa strategi yang dilakukan Panti yaitu sebagai berikut:

1. Menjalankan beberapa usaha bisnis

Panti Asuhan Putri Aisyiyah Babat menjalankan beberapa usaha bisnis. Usaha yang dijalankan oleh panti saat ini sebanyak 5 jenis usaha, terdiri dari distributor air minum Q-Mas, Catering As-Sakinah, Toko AsSakinah, Tas Kain As-Sakinah dan Capcin As-Sakinah.

Menjalankan lebih dari satu jenis usaha membuat pendapatan yang diperoleh panti cukup besar. Bidang usaha dengan penghasilan tertinggi yang dijalankan oleh Panti Asuhan Putri Aisyiyah Babat cenderung mengarah pada makanan dan minuman.
Berdagang menjadi salah satu strategi Panti Asuhan Putri Aisyiyah Babat dalam mencapai kemandirian finansial yang diperbolehkan dalam Islam. Hal ini tertulis pada QS An-Nisa ayat 29.

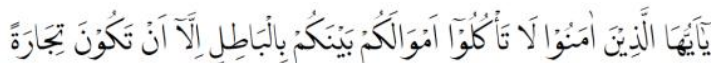

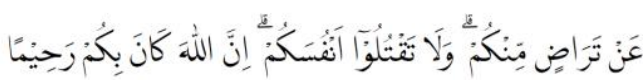

yā ayyuhallażīna āmanụ lā ta`kulū amwālakum bainakum bil-bāțili illā an takụna tijāratan 'an tarāḍim mingkum, wa lā taqtulū anfusakum, innallāha kāna bikum rahịmā

Artinya: "Wahai orang-orang yang beriman! Janganlah kamu saling memakan harta sesamamu dengan jalan yang batil (tidak benar), kecuali dalam perdagangan yang berlaku atas dasar suka sama suka di antara kamu. Dan janganlah kamu membunuh dirimu. Sungguh, Allah Maha Penyayang kepadamu." (QS An-Nisa ayat 29)

2. Sistem Manajemen Keuangan Mandiri

Pada umumnya pelaksanaan manajemen kevangan yang dilakukan Panti Asuhan Putri Aisyiyah Babat tidak jauh berbeda dengan lembaga lain sebagaimana sesuai dengan teori-teori yang telah ada yaitu perencanaan, pengorganisasian, pelaksanaan dan pengendalian keuangan.

Satu hal yang menarik tentang Panti Asuhan Putri Asiyiyah Babat 
dalam strateginya mencapai kemandirian finansial terkait manajemen keuangan adalah panti tidak menggunakan dana dari donasi sebagai opsi utama dalam pembelanjaan. Panti selalu berusaha mengoptimalkan penggunaan dana hasil usaha untuk memenuhi kebutuhan sehari-hari. Dana dari donasi kemudian di simpan di Baitul Tanwil Muhammadiyah (BTM) Mulia agar bermanfaat bagi pihak lain sebagai pembiayaan, khususnya donasi yang bersifat tidak tetap. Penggunaan dana donasi yang disimpan di Baitul Tanwil Muhammadiyah Mulia biasanya digunakan untuk membiayai kebutuhan dalam jumlah besar.

3. Menentukan prioritas sumber penerimaan

\section{Berdasarkan pembahasan} laporan kevangan pada poin 4.3.2, selama ini Panti Asuhan Putri Aisyiyah Babat masih menerima donasi dari pihak eksternal. Hal yang dikhawatirkan adalah bagaimana jika suatu ketika panti tidak mendapat donasi dan mengalami defisit untuk memenuhi kebutuhannya. Jika hal tersebut terjadi, maka pengurus akan melihat seberapa besar kekurangan dananya, apabila masih dalam jumlah yang kecil, pengurus akan melakukan iuran untuk menutupi kekurangan tersebut. Namun jika kekurangan dananya dalam jumlah yang besar, pengurus akan berusaha meningkatkan produksi usaha agar menghasilkan profit yang lebih tinggi. Kemudian jika hal tersebut masih tidak dapat menutupi kekurangan dana Panti Asuhan Putri Aisyiyah Babat, maka pengurus akan menggunakan dana di Baitul Tanwil Muhammadiyah Mulia. Dengan langkah terakhir, jika kebutuhan masih tidak tercukupi maka pengurus akan mengajukan permohonan bantuan dana kepada pihak-pihak eksternal seperti Kemensos dan Dinas Sosial.

Panti Asuhan Putri Aisyiyah Babat kemudian menentukan urutan sumber dana yang diprioritaskan oleh Panti Asuhan Putri Aisyiyah Babat dalam menghadapi kondisi defisit. Pemilihan sumber dana dimulai dari sumber dana internal terlebih dahulu kemudian ketika kondisi masih tidak mencukupi maka akan mencari sumber dana eksternal, namun dana eksternal tersebut bukan berupa pinjaman, melainkan pengajuan proposal dana ke lembaga tertentu.

4. Menumbuhkan jiwa mandiri anak asuh

Panti Asuhan Putri Aisyiyah Babat menyadari pentingnya menanamkan jiwa kemandirian dalam diri anak asuh. Saat ini seseorang dituntut untuk memiliki 
kecakapan hidup sebagai bekal untuk memulai kemandirian hidup di masa depan. Kemandirian hidup sangat diperlukan dikondisi yang minim lapangan kerja seperti di negara kita saat ini. Oleh sebab itu kecakapan hidup menjadi sangat penting sebagai bekal seseorang dalam meningkatkan kemampuan, kesanggupan, dan keterampilan yang diperlukan oleh untuk menjaga kelangsungan hidup serta pengembangan dirinya (Depdiknas., 2002).

Jiwa kemandirian dan kewirausahaan ini dibentuk dengan memberi berbagai jenis pelatihan keterampilan pada anak asuh. Keterampilan tersebut berupa pelatihan membuat roti, membuat kue, membuat mie instan, dan pelatihan menjahit. Tentunya hal tersebut dilakukan agar selepas dari panti asuhan, anak asuh dapat menopang kehidupannya dengan mandiri dan tidak lagi bergantung pada orang lain.

5. Menanamkan jiwa suka berbagi pada diri anak asuh

Strategi ini dilakukan karena panti ini tidak hanya menerima bantuan dan dipergunakan untuk dirinya saja, melainkan juga berbagi kepada sesama. Para pengurus yakin bahwa ketika mereka sering berbagi kepada sesama, maka Allah
SWT akan memudahkan rezeki mereka.

Pandangan masyarakat kepada anak panti asuhan yang dinilai hanya menerima dana donasi saja, ingin beliau hilangkan dengan menanamkan sifat berbagi pada anak-anak. Setiap tahun, dana untuk bakti sosial selalu dianggarkan dalam penyusunan Rencana Anggaran Panti (RAP).

Berbagi kepada sesama termasuk salah satu strategi Panti Asuhan Putri Aisyiyah Babat dalam mencapai kemandirian finansial karena hal itu tentunya akan membawa berkah bagi Panti Asuhan Putri Aisyiyah Babat sendiri agar bisa menjalankan usaha-usaha dengan lancar dan membuahkan hasil.

Bakti sosial dilaksanakan ke beberapa panti asuhan lainnya dan ke Qoriyyah Thayyiban di sekitar Babat dan Lamongan. Bakti sosial dilakukan dengan membagikan beberapa sembako juga ilmu pengetahuan kepada sasaran baksos. IImu yang diberikan berupa ilmu agama dan juga keterampilanketerampilan yang dimiliki anak-anak asuh Panti Asuhan Putri Aisyiyah Babat.

Dalam mengelola usaha bisnis, dibutuhkan adanya manajemen yang baik, mulai dari proses perencanaan, pengorganisasian, pelaksanaan, hingga pengendalian. Namun dibalik 
Gustami, et al/Jurnal Ekonomi Syariah Teori dan Terapan Vol. 6 No. 7 Juli 2019: 1509-1520; UPAYA PANTI ASUHAN PUTRI AISYIYAH BABAT LAMONGAN SEBAGAI STRATEGI MENCAPAI KEMANDIRIAN FINANSIAL

manajemen yang baik, pasti ada kalanya kendala atau hambatan juga akan dihadapi. Beberapa kendala yang dihadapi Panti Asuhan Putri Aisyiyah Babat dalam mengelola usahanya antara lain :

1. Pembukuan hasil usaha

Salah satu kendala yang dialami Panti Asuhan Putri Aisyiyah Babat adalah tidak melakukan pencatatan secara detail atas transaksi usaha. Hal ini membuat hasil dari penjualan tidak dapat dilihat keberhasilannya. Kendala ini juga disebabkan karena kurangnya pengetahuan para penanggung jawab usaha akan tata cara pencatatan.

2. Risk Aversion

Para pengurus lebih bersikap risk aversion dalam mengambil keputusan usaha, mereka takut akan risiko kerugian ketika harus memperbesar usaha. Harapan para pengurus saat ini adalah bagaimana agar usaha tersebut tetap berjalan lancar meskipun dengan profit yang tidak begitu besar namun tetap bisa mengedukasi anak asuh dalam berwirausaha.

3. Sumber Daya Manusia

Kendala yang dialami Panti Asuhan Putri Aisyiyah Babat dalam hal sumber daya manusia ialah keterbatasan jumlah karyawan. Saat ini karyawan yang dimiliki Panti Asuhan Putri Aisyiyah Babat sebanyak 14 orang, belum lagi semua karyawan tersebut sifatnya hanya relawan bukan karyawan tetap.

4. Strategi Pemasaran

Kendala selanjutnya yang dialami Panti Asuhan Putri Aisyiyah Babat dalam mengelola usahanya yaitu strategi dalam pemasaran. Hal ini berkaitan dengan keterbatasan sumber daya manusia (SDM), dengan minimnya sumber daya manusia yang mengelola usaha maka timbul kesulitan dalam mengatur target pemasaran. Usaha bisnis Panti Asuhan Putri Aisyiyah Babat mengalami pertumbuhan yang lambat dikarenakan kurang adanya strategi pemasaran yang luas dan terkoordinasi dengan baik.

\section{SIMPULAN}

Berdasarkan hasil dari pembahasan dapat disimpulkan bahwa Panti Asuhan Putri Aisyiyah Babat sudah dapat dikatakan mandiri secara finansial karena prosentase komponen sumber modal $75 \%$ berasal dari hasil pengelolaan usaha. Dari kelima strategi kemandirian finansial tersebut maka dapat disimpulkan bahwa pengelolaan bisnis dan keuangan yang baik akan mendorong Panti Asuhan Putri Aisyiyah Babat mencapai kemandirian finansial, hal ini ditunjukkan dengan peningkatan prosentase sumber dana yang berasal dari hasil usaha setiap tahunnya. 
Gustami, et al/Jurnal Ekonomi Syariah Teori dan Terapan Vol. 6 No. 7 Juli 2019: 1509-1520; UPAYA PANTI ASUHAN PUTRI AISYIYAH BABAT LAMONGAN SEBAGAI STRATEGI MENCAPAI KEMANDIRIAN FINANSIAL

Strategi yang dilakukan Panti Asuhan Putri Aisyiyah Babat untuk mencapai kemandirian finansial antara lain: menjalankan beberapa usaha bisnis, sistem manajemen keuangan yang mandiri, menentukan prioritas sumber penerimaan, menanamkan jiwa kemandirian dan kewirausahaan anak asuh dan menumbuhkan jiwa suka berbagi pada diri anak asuh.

Kendala dalam pengelolaan usaha pasti dialami semua pihak yang melakukannya, begitu pula dengan Panti Asuhan Putri Aisyiyah Babat. Beberapa kendala yang dialami panti dalam mengelola usaha bisnisnya antara lain:

1) Pembukuan hasil usaha tidak dilakukan secara detail sehingga kesulitan dalam melihat keberhasilan tiap sub usaha.

2) Pengurus Panti Asuhan Putri Aisyiyah Babat cenderung bersifat risk aversion dalam pengambilan keputusan usaha.

3) Keterbatasan sumber daya manusia untuk melakukan proses produksi sampai penjualan setiap sub usaha.

4) Strategi pemasaran produk yang belum maksimal.

Panti Asuhan Aisyiyah Babat sebaiknya lebih menggerakkan roda bisnis yang telah ada, sehingga hal tersebut bisa meningkatkan kemandirian panti. Tentunya hal tersebut diikuti oleh pengelolaan bisnis dan keuangan yang lebih baik, mulai dari manajemen bisnis dan pencatatan keuangan.

\section{DAFTAR PUSTAKA}

Arikunto, S. 2002. Metodologi Penelitian Suatu Pendekatan Proposal. Jakarta: PT. Rineka Cipta.

Barzan, Bardawi. 1999. Psikologi Perkembangan Anak..Jakarta: Rineka Cipta.

Chaplin,J.P. 1996. Kamus Besar Psikologi. Jakarta: Rajawali Press

Departemen Agama RI. 1993. Al-Qur'an Dan Terjemahannya.

Departemen Sosial RI. 1999. Pedoman Perlindungan Anak. Jakarta: Direktorat Jendral Bina Kesejahteraan Sosial Anak Keluarga dan Lanjut Usia

Moleong,L.J.2010. Metodologi Penelitian Kualitatif. Bandung: Remaja Rosdakarya.

Parker, Deborah,.2006. Menumbuhkan Kemandirian dan Harga Diri Anak. Jakarta: Prestasi Pustakaraya

Sugiyono. 2012. Metode Penelitian Kuantitatif Kualitatif dan R\&D. Bandung: Alfabeta.

Yin, Robert. K, 2009, Studi Kasus; Desain dan Metode, Jakarta; Raja Grafindo Persada.

Tjiptono, Fandy. 2006. Strategi Pemasaran. Yogyakarta: Andi Offset.

Kotler, Philip. 2000. Manajemen Pemasaran di Indonesia: Analisis, Perencanaan, implementasi dan 
Pengendalian. Alih Bahasa,

Susanto, A.B. Jakarta: Penerbit

Salemba Empat

Rangkuti,Freddy. 2013. Analisis SWOT :

Teknik Membedah Kasus Bisnis.

Jakarta : PT. Gramedia Pustaka

Utama

Undang-Undang Nomor 23 Tahun 2002

tentang Perlindungan Anak

Departemen Sosial Republik Indonesia.

2004. Acuan Pelayanan Sosial

Anak di Panti Sosial Asuhan

Anak. Jakarta : Departemen

Sosial Republik Indonesia

www.bps.go.id

Ridwan S. Sundjaja dan Inge Barlian,

2002. Manajemen Keuangan

Satu Edisi Keempat. Jakarta:

Prenhallindo.

Pearce II, John A. dan Robinson Richard

B.Jr. 2008. Manajemen Strategis

10. Jakarta: Salemba Empat.

Tarmidzi, Rosmiaty. 2010. Pendapatan

Asli Daerah Berdampak Pada

Kemandirian Kevangan Daerah.

Jurnal Akuntansi dan Keuangan

Vol. 1 No.1 Hal. 123-128.

Halim, Abdul. 2007. Akuntansi Keuangan

Daerah. Jakarta: Salemba

Empat.

Halim, Abdul. 2002. Manajemen

Keuangan Daerah Bunga

Rampai. Yogyakarta: UPP AMP

YKPN Yogyakarta. 